\title{
Shape Grammar as a Typology Defining Tool for Ancient Egyptian Funerary Monuments
}

\author{
Anja Wutte ${ }^{1} \mathbb{D} \cdot$ José Pinto Duarte ${ }^{2} \mathbb{C}$
}

Accepted: 25 November 2020 / Published online: 16 January 2021

(c) The Author(s) 2021

\begin{abstract}
This paper proposes a parametric shape grammar for ancient Egyptian funerary monuments. The corpus of monuments includes ten rock-cut structures, duly documented. They exhibit different grades of completion and preservation and possess variant archaeological documentation. The generation of a design following the proposed grammar depends both on formal and functional aspects. Metadata indicates the evidential value and numerical occurrence of rules in the generation of designs. The developed grammar can be used to reconstruct unfinished tombs, extend an existing one, or generate new designs according to the rules. It denotes the linear and symmetric structure characteristic of the monuments and reflects the chronological sequence of construction. The proposed grammar encodes the typology of the studied monuments and suggests that ancient Egyptian architecture may have implied a clear set of canons that may be made explicit by developing additional grammars for other building types.
\end{abstract}

Keywords Shape grammar · Ancient Egyptian architecture $\cdot$ Rock-cut funerary monuments $\cdot$ Late period private tombs

\section{Introduction}

This paper presents an analytical grammar for ancient Egyptian funerary architecture. It is the first approach in analyzing ancient Egyptian architecture using algorithmic or procedural modeling methods. The parametric grammar describes the formal structure

Anja Wutte

office@anjawutte.com

José Pinto Duarte

jxp400@psu.edu

1 Digital Architecture Group, Center for Geometry and Computational Design, TU Wien, Vienna, Austria

2 Stuckeman Center for Design Computing, Stuckeman School of Architecture and Landscape Architecture, Pennsylvania State University, State College, Pennsylvania, USA 
of ten Late Period funerary monuments at Thebes. The proportionate simplicity and regularity of the studied funerary monuments make them particularly amenable to the development of a grammar. Furthermore, Egyptian funerary monuments of the studied period have a self-contained corpus of style that depended on the social status of the owner, on the time available for carving it, and the specific conditions of the location where they were built, as follows: the higher the status of the tomb's owner, the more intricate and elaborate the tomb; the longer the period in power of the owner, the bigger and more elaborate the tomb; the larger the underground area and the higher the quality of the soil, the deeper and wider the rooms and the tomb. The style of the monuments also depended on the time and location when and where they were built. This means that the corpus of buildings is dense and contained and is not likely to be found at other locations or in other periods.

The research described in this paper is part of a larger project that analyzes ancient Egyptian funerary monuments from the Late Period located at Thebes West, the west bank of Luxor. The goal of the project is to develop an analytical method to characterize ancient monuments and encode the results into a shape grammar (Stiny and Gips 1972). Shape grammars offer a rigorous, systematic way to study Egyptian architecture and compare different building corpora. Since George Stiny and William Mitchell published the first analytical shape grammar for Palladian villas (Stiny and Mitchell 1978) a number of grammars have been developed to analyze different building types: Bungalows in Buffalo (Downing and Flemming 1981); Frank Lloyd Wright's prairie houses (Koning and Eizenberg 1981); and traditional Chinese buildings (Li 2001), just to mention a few. Recently, shape grammars have been used to study and reconstruct architecture based on archaeological remains, such as Inca architecture (Mackay and Silva 2012) or Greek and Roman libraries (Mamoli 2019). This paper presents an analytical shape grammar for Late Period rock-cut funerary monuments developed with aim of generating the ten examined monuments, but with enough flexibility to also compute non-existing or not yet discovered examples in the same style.

Previous work (Wutte et al. 2015; Wutte 2018) focused on the analysis of spatial characteristics, proportion, accessibility, and lighting features of the funerary monuments, as well as on occurrence and distribution of decoration in its rooms. The present work addresses the development of a shape grammar to describe the formal structure of the same monuments. The paper is organized as follows. First, the architectural morphology of the complexes, as well as the existing documentation, are introduced. Second, the set of rules of the proposed grammar are presented. Third, the derivation of the layout of one of the existing monuments is described as an example. Finally, further possible outcomes and possibilities of the use of shape grammars in archaeological studies are discussed.

\section{Corpus of Monuments}

The upper Egyptian area of Thebes gained importance since at least the Eleventh Dynasty. The city of Thebes was not only the capital during the Eleventh Dynasty but also became an administrative and cultural center as well as a necropolis for 
kings and private people. Even when the administrative capital moved to the North, Thebes continued to be the main pharaonic necropolis, a cult center, and the king's residence.

The corpus of studied funerary monuments includes ten monumental rockcut structures, which are documented adequately. They possess variant degrees of completion, archaeological documentation, and preservation, but have homogeneously drawn floorplans in common. The studied corpus includes the tombs of Harwa, Karabasken, Karakhamun, Montuemhat, Padiamenope, Irtieru, Pabasa, Padihorresnet, Ankh Hor and Padineith.

The architecture is divided into three vertical levels comprising a superstructure, a substructure, and a burial area. The superstructure was built out of mudbricks and located at the surface (Figs. 1, 2, 3) and, therefore, was visible to a large extent.

The superstructures were built above the substructure. Just as the whole complex had three vertical levels (Fig. 2), the superstructure includes three horizontal areas, comprising three adjacent, open-from-above courtyards of large dimensions. Within the second courtyard, on a lower level, was located the open courtyard of the substructure (Eigner 1984: Figs. 29, 113). Not all the tombs appear to have had a superstructure, as Egyptologists have only found proof for this kind of structure (Eigner 1984: 40-42, 46-48, 70-81) for the monuments of Montuemhat, Karabasken, Karakhamun, Padiamenope, Pabasa and Ankh Hor. Furthermore, they were constructed with mudbricks, hence only fragments are preserved in some of them. The relatively bad state of preservation and unrepresentative number of examples is the reason why the superstructure was not explicitly considered in the development of the proposed grammar.

Regarding the substructure, a threefold sequence is also identifiable, including courtyard, halls, and sanctuary. The courtyard is open and observable from above (Fig. 4). It can have non-bearing pillars and is generally decorated. The courtyard leads into the rock-cut area of the complex. This entire level is carved into the local rock. The courtyard is usually followed by a niche entrance, except in the two cases of Montuemhat and Pabasa. From the substructure, the burial area could be accessed through shafts, ramps, and/or staircases. The burial area was also not considered in

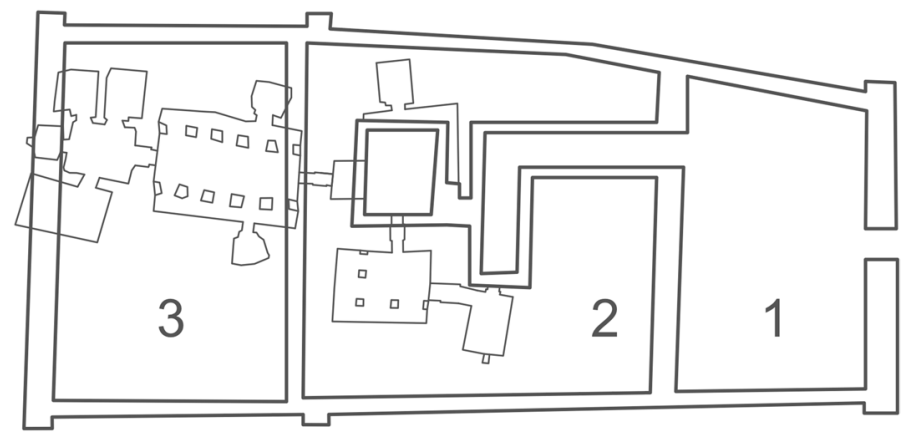

Fig. 1 Drawing of Ankh Hor showing the threefold superstructure and substructure on the top of each other. Image: after (Eigner 1984: 148) 


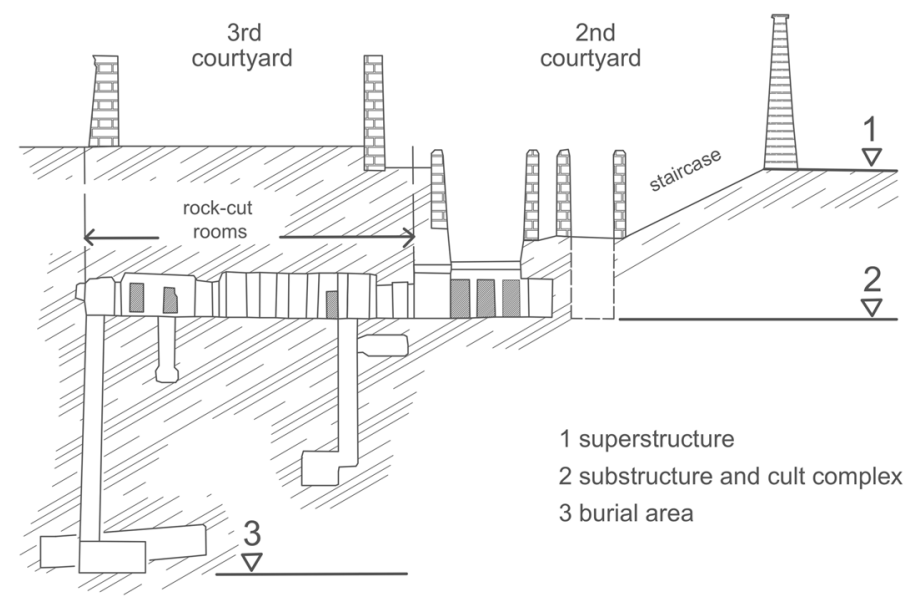

Fig. 2 Section of Ankh Hor. Vertical levels of Superstructure, substructure, and burial area. The courtyard of the substructure is located under the second courtyard of the superstructure. Image: after (Eigner 1984: 154)

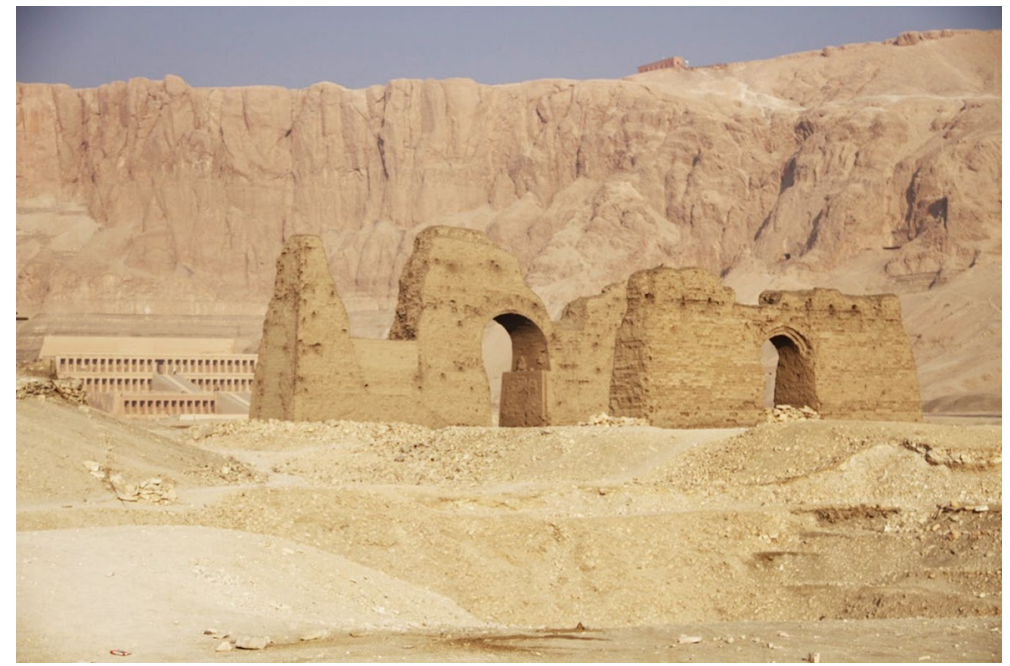

Fig. 3 Superstructure of Montuemhat. In the background is the temple of Hatshepsut

the proposed grammar, because they are not entirely documented, and the data is consequently underrepresented.

The proposed grammar was developed from a corpus of ten rock-cut substructures, including their open courtyards, the rock-cut rooms and the entrance areas, as long as they were preserved and documented. The earliest reference to these monuments dates back to the eighteenth century, when Richard Pococke (1743) visited the site. Further expeditions followed, such as those by Giovanni Belzoni (1821), Robert Hay (1824), and Karl Lepsius (1849). Much of the documentation 


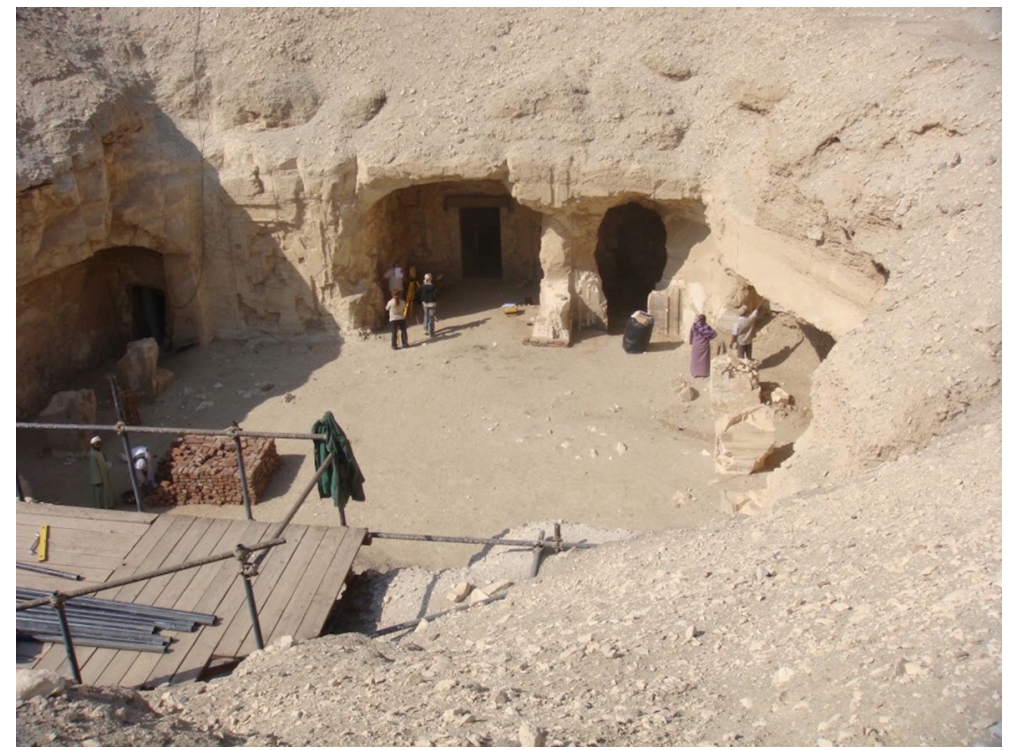

Fig. 4 Courtyard of the substructure of Harwa

that resulted from these visits is not very detailed but constitutes the only source of information in some cases. Parts of the structures are severely damaged, due to both man-made and natural damages, such as floods, salt efflorescence or collapses. This is, for example, the case of the tomb of Irtieru, which is currently being excavated, documented, and reconstructed by Elena Pischikova (publication pending). Lepsius's drawings from his expedition are of great help for cleaning and reconstructing wall decorations. Elena Pischikova's team is also working on the tombs of Karakhamun and Karabasken, which are cleaned, recorded, and reconstructed. The progress of the excavations can be monitored online and through periodic publications (Pischikova 2014; Pischikova 2017; Pischikova et al. 2014; Pischikova et al. 2018). The monument of Ankh Hor was excavated and reconstructed in the 1970s by Manfred Bietak and the Österreichisches Archäologisches Institut (Bietak and ReiserHaslauer 1978, 1982). The excavation publications are very detailed, including archaeological documentation, stratigraphical details, findings, and discussion about architecture, as well pictorial and textual inscriptions. The tomb of Pabasa was excavated during 1918 and 1919 (Lansing 1920) and reconstructed in the 1980s (Nasr 1985). Publications have concentrated on pictorial and textual studies, such as the most recent report by Alessio Corsi (2017). For instance the tomb of Pabasa, and the monuments of Padihorresnet (Graefe 2003) and Padiamenope (Traunecker 2014, 2018) are relatively well preserved and publications refer mainly to inscriptions and art. The excavations of the monument of Harwa have been underway since 1995, but documentation includes mainly short reports (Tiradritti 2004, 2015) and a comprehensive publication of the excavation is still pending. Montuemhat was partially cleared and restored in 1984 by the Egyptian Antiquities Organization. New investigations have taken place since 2006 by Farouk Gomaà (2006), with 
projects involving the documentation of decoration (Gestermann and Gomaà 2018). Padineith is only published in an excavation report by Gomaà (2004).

In 1984 Diethelm Eigner published an overview of Late Period monumental tombs of Thebes, in which he updated and complemented in terms of geodesic data existing plans and reconstructions from monographs and building documentations, collected by J. Dorner. His work includes descriptions of building elements and construction techniques, as well as of the functions of spaces. He also addresses cultural and historical aspects of the building functions, such as the relation to residential houses (Eigner 1984: 91-102) and the connection to the Osiris tomb (Eigner 1984: 163-183). Construction specifications are defined individually for each monument with references and links to literature references and former plans. The floorplans of Eigner and Dorner (1984) as well as recent excavation reports were the sources for analyzing the architectural structures. The floorplans were digitalized and served as the basis for developing the shape grammar (Fig. 5).

The substructures of the funerary monuments are organized on a somewhat straight longitudinal axis and then spread to the sides. The structure on the main axis generally contains the open courtyard, a niche entrance, one or two halls, sometimes a sanctuary hall, and the sanctuary. To the sides, somewhat symmetrically, the courtyard and halls can open to lateral naves including non-bearing pillars (Eigner 1984: 120) and additional side annexes. The architecture of the tombs has an underlying symmetrical formal structure, which can lead to more (Fig. 5e) or less (Fig. 5c) symmetrical floorplans. The entrance area can have different configurations and orientations, and can include a ramp, a staircase, a vestibule, and an antechamber.

\section{Shape Grammar}

The analysis of the funerary monuments reveals an underlying linear and symmetrical pattern. Generally, the structures proceed into the depths along a longitudinal main axis (MA), connecting the open courtyard to the sanctuary, and open to the sides along transversal side axes (SA). The extensions into the depth, as well as to the sides, have a maximal three-level gradation in common. This threefold sequence is already known from the vertical and horizontal sequences mentioned above. For the side rooms, this means a maximum of two consecutive rooms after the main nave, which represents gradation level one.

The developed shape grammar was developed in the Cartesian product of the algebras $\mathrm{U}_{12} \mathrm{~V}_{02}$ as arrangements of lines and labelled points on the plane. It contains thirty-three rules and is organized in five stages. The schemata of stages I to III are organized in chronological sequence of construction (Eigner 1984: 67-70, 82-84). They represent the successive steps of work required to build a tomb, according to the state of archaeological evidence. Most of grammar's rules are parameterized, and the parameters are summarized in Table 1, which shows the names and functional abbreviations of rooms, as well as the ranges of possible values for their dimensions and angles, which were extracted from the analyzed tombs in the corpus. Measurements derive from geodesic data that Eigner and Dorner (1984) collected 


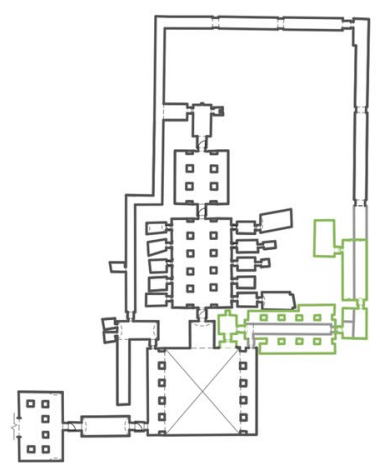

Harwa/ Akhimenru

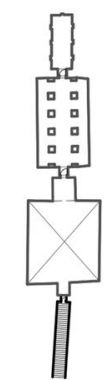

Karabasken

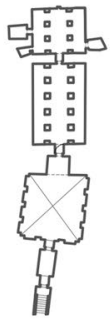

Karakhamun
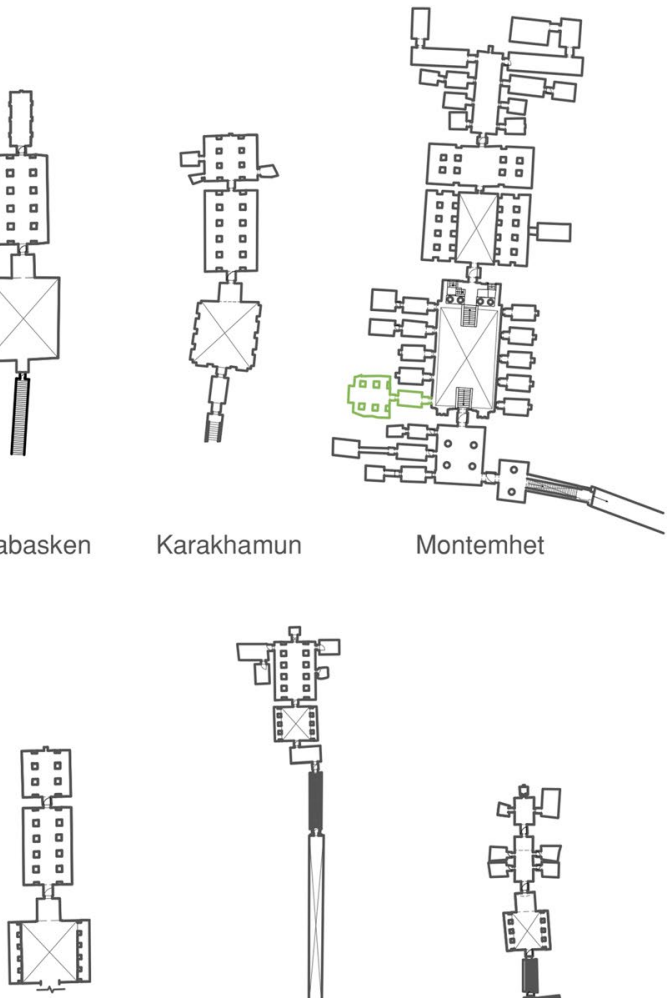

Irtieru

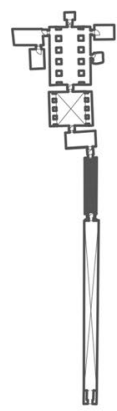

Pabasa

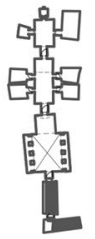

Padihorresnet

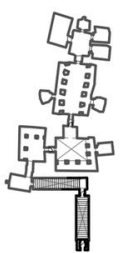

Ankh Hor

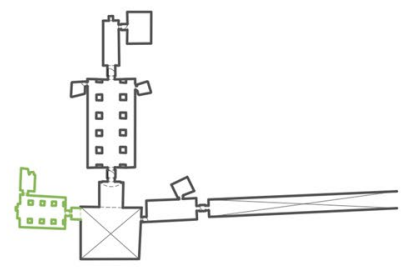

Padineith

Fig. 5 Substructures of the analyzed monuments (green: secondary tomb built later on). Scale: 1:1150

and published as plans. Original plan dimensions may be distorted due to several factors, including: (1) building inaccuracies during the construction of monuments, for instance, by reaching weak quality stone or former tombs; (2) conservation status, caused by damages or collapses and re-use of the tombs for modern housing or graves; (3) measurement errors during the digitization process, and (4) the status of excavation and documentation, which might still be incomplete. Measurements are represented in the ancient Egyptian metric system of cubits $c$. One cubit is based 
Table 1 Names, abbreviations, and ranges of parameter variation for the dimensions and angles of rooms in the tombs

\begin{tabular}{|c|c|c|c|c|}
\hline Name & Abbreviation & Length (min., max.) & Width (min., max.) & Angle (min., max.) \\
\hline Courtyard & $\mathrm{CR}$ & {$[12 \mathrm{c}, 32 \mathrm{c}]$} & {$[10 \mathrm{c}, 28 \mathrm{c}]$} & $\alpha=\left[85^{\circ}, 94^{\circ}\right]$ \\
\hline Colonnades courtyard & $\mathrm{CCR}$ & {$[49 \mathrm{c}, 49.5 \mathrm{c}]$} & {$[23 \mathrm{c}, 23.5 \mathrm{c}]$} & \\
\hline Niche entrance & $\mathrm{NE}$ & {$[5 \mathrm{c}, 10 \mathrm{c}]$} & {$[5 \mathrm{c}, 10 \mathrm{c}]$} & \\
\hline Intermediate space & IS & {$[0.2 \mathrm{c}, 4.8 \mathrm{c}]$} & {$[1.7 \mathrm{c}, 3.5 \mathrm{c}]$} & \\
\hline Passageway & $\mathrm{P}$ & {$[0.0 \mathrm{c}, 10.6 \mathrm{c}]$} & {$[1.2 \mathrm{c}, 2.8 \mathrm{c}]$} & \\
\hline Pillared hall & $\mathrm{PH}$ & {$[15 \mathrm{c}, 32 \mathrm{c}]$} & {$[6.2 \mathrm{c}, 6.8 \mathrm{c}]$} & $\alpha=\left[81^{\circ}, 98^{\circ}\right]$ \\
\hline Hall & $\mathrm{H}$ & {$[8 \mathrm{c}, 20 \mathrm{c}]$} & {$[6 \mathrm{c}, 8 \mathrm{c}]$} & \\
\hline Sanctuary hall & SYH & {$[11 \mathrm{c}, 13 \mathrm{c}]$} & {$[6 \mathrm{c}, 8 \mathrm{c}]$} & \\
\hline Sanctuary & SY & {$[0.2 \mathrm{c}, 2.4 \mathrm{c}]$} & {$[0.7 \mathrm{c}, 3.6 \mathrm{c}]$} & \\
\hline Side room & $\mathrm{S}$ & {$[3 \mathrm{c}, 27 \mathrm{c}]$} & {$[2.5 \mathrm{c}, 11 \mathrm{c}]$} & $\alpha=\left[72^{\circ}, 105^{\circ}\right]$ \\
\hline Annex & AN & {$[5 \mathrm{c}, 5.5 \mathrm{c}]$} & {$[4.4 \mathrm{c}, 5.5 \mathrm{c}]$} & \\
\hline Lateral nave & NA & {$[14 \mathrm{c}, 32 \mathrm{c}]$} & {$[3 \mathrm{c}, 7.6 \mathrm{c}]$} & \\
\hline Nave component & $\mathrm{NC}$ & {$[3 \mathrm{c}, 6.6 \mathrm{c}]$} & $\mathrm{W}_{\mathrm{na}}$ & \\
\hline Vestibule & VB & {$[8 \mathrm{c}, 18 \mathrm{c}]$} & {$[5 \mathrm{c}, 8 \mathrm{c}]$} & \\
\hline Antechamber & $\mathrm{AC}$ & {$[6.5 \mathrm{c}, 21.5 \mathrm{c}]$} & {$[3.5 \mathrm{c}, 9 \mathrm{c}]$} & $\alpha=\left[88^{\circ}, 90^{\circ}\right]$ \\
\hline Staircase & $\mathrm{SC}$ & {$[12 \mathrm{c}, 20 \mathrm{c})$} & {$[4 \mathrm{c}, 6 \mathrm{c}]$} & $\alpha=\left[82^{\circ}, 90^{\circ}\right]$ \\
\hline Ramp & $\mathrm{RP}$ & {$[67 \mathrm{c})$} & {$[5 \mathrm{c}, 7 \mathrm{c}]$} & \\
\hline Corridor & $\mathrm{CO}$ & {$[14 \mathrm{c}, 69 \mathrm{c}]$} & {$[3 \mathrm{c}, 6 \mathrm{c}]$} & \\
\hline Niche & NI & {$[1 \mathrm{c}, 1.2 \mathrm{c}]$} & {$[1.5 \mathrm{c}, 1.7 \mathrm{c}]$} & \\
\hline Main axis & MA & & {$[0 \mathrm{c}, 3 \mathrm{c}]$} & $\beta=\left[88^{\circ}, 105^{\circ}\right]$ \\
\hline Side axis & SA & & {$[0 \mathrm{c}, 1.5 \mathrm{c}]$} & $\beta=\left[80^{\circ}, 99^{\circ}\right]$ \\
\hline Pillar & PI & {$[0.9 \mathrm{c}, 2.8 \mathrm{c}]$} & {$[0.9 \mathrm{c}, 2.8 \mathrm{c}]$} & $\alpha=\left[71^{\circ}, 106^{\circ}\right]$ \\
\hline Column & $\mathrm{CO}$ & & $\mathrm{d}=[1.5 \mathrm{c}, 2 \mathrm{c}]$ & \\
\hline
\end{tabular}

Unit measurement $\mathrm{c}$ is one cubit, based on a forearm length and corresponding to $0.525 \mathrm{~m}$

on a forearm length and corresponds to $0.525 \mathrm{~m}$ (Bagnall 2009: 186). In the shape rules schemata, the parameters of length and width are indicated with $w$ and $l$ and their subsequent representatives with $w_{1}, l_{1}$, and so on. The term width is used for dimensions measured horizontally, which represents walls parallel to the front of a tomb's layout. The term length refers to dimensions perpendicular to the previous walls. Relevant angles are denoted with $\alpha$. Additional angles of quadrilateral shapes representing rooms are dependent from $\alpha$ so that their sum is $360^{\circ} . \beta$ denotes the angle of a room relative to the main axis if it differs from $90^{\circ}$. Conditions and functional conditions are specified as extensions of the shape grammar formalism and specify dimensional and functional dependencies. Conditions refer to the ranges of possible values for length and width of a space in Table 1 and include dimensional conditions. Dimensional conditions propose possible relationships between dimensions according to analyzed proportions and proportion relations of rooms. Functional conditions impose on certain rule schemata, where labels $f_{1}$ and $f_{2}$ denote the functions of rooms. Due to space limitations, functional conditions are 
only presented for rules 1-4 (Fig. 6). The number of monuments in whose generation a rule is used is denoted by the numerator of a fraction called evidence. For instance, the evidence of a rule used in the generation of nine of the ten monuments is $9 / 10$.

\section{Stages I to III: Basic Shape, Lateral Naves and Pillars, Lateral Annexes}

Stage I contains rules 1-4, which generate the basic shape of a tomb's substructure (Fig. 6). The basic shape is generated along the tomb's main axis, which is introduced with the initial shape. The initial shape is a labelled shape that contains a straight dashed line, representing the main axis, a black arrow label, representing the direction in which additional rooms can be added, and a labelled point 0 , representing the origin of the Cartesian system in reference to which the tomb's layout is generated. Rule 1 adds the initial courtyard that exists in every tomb. Rule 2 creates a variation of the courtyard, which is lowered in the center and with a podium along the four sides, and includes columns on one of the smaller sides and niches on the other. This type of courtyard is only present in the monument of Montuemhat (Fig. 5). Rule 3 and 4 add spaces along the MA.

Stage II includes rules to add lateral naves and pillars (Fig. 7). While during stage I spaces were added along the main axis, in stage II spaces are added to the sides, along the side axes. White arrow labels indicate how shapes can be added along the side axis. Rules 5 and 6 add one or at most two lateral naves to a central nave. With rule 8 a corner nave can be added, as represented in the tomb of Ankh Hor (Fig. 5). Rules 7, 9 and 10 subdivide naves into square-shaped areas and these into further subdivisions. Rules 11 to 13 represent the construction step of tearing down the walls between pillars. They encode the chronology of the carving technique followed when creating pillars in the courtyard and halls. Rules 14 to 16 are used to add, remove, or extend pilasters, while rule 17 turns pillars into columns. Pillars represent square piers, while columns are round. Pilasters are half pillars attached to the wall and not free standing. Some of these rules are used only once or never explicitly used in the generation of the tombs in the corpus, but they were added to the shape grammar according to the same formal logic used to infer the other rules, and make hypothetical tombs possible.

Stage III contains rules 18 to 25 , which add lateral annexes, niches, or additional corridors (Fig. 8).

\section{Stage IV to V: Changing Labels and Axes, Passageways, and Doorframes}

Stage IV rules 26-31 change or delete labels and axes (Fig. 9). They include rules to delete labels but also to change a white label into a black label, which means changing MA into SA. This occurs only when a new tomb is added to an existing structure (Fig. 5a). Rule 26 reverses a MA black label as a function of adding a sanctuary (Fig. 12). The sanctuary is the most sacred place in the monument, and it can take the form of a niche or a small room. The step to 
1 Adding the initial courtyard

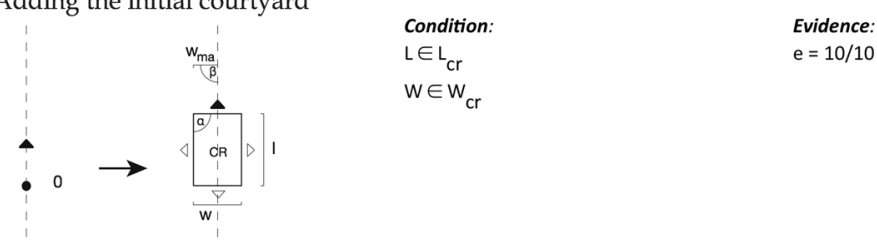

2 Building a colonnades courtyard

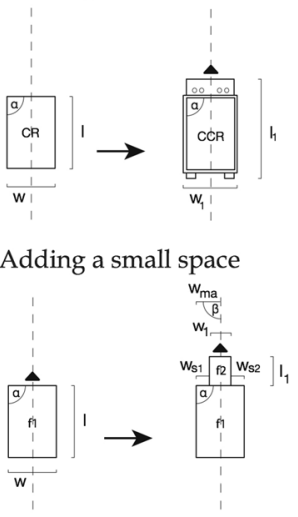

$$
\begin{aligned}
& \text { Condition: } \\
& \mathrm{L} \in \mathrm{L}_{\mathrm{cr}} \\
& \mathrm{w} \in \mathrm{w}_{\mathrm{cr}} \\
& \mathrm{L}_{1} \in \mathrm{L}_{\mathrm{ccr}} \\
& w_{1} \in w_{\text {ccr }}
\end{aligned}
$$

Evidence:

$\mathrm{e}=1 / 10$

$$
\begin{aligned}
& \text { Condition: } \\
& L \in\left\{L_{c r} L_{h}, L_{s y h}\right\} \\
& W \in\left\{W_{c r}, W_{h^{\prime}}, W_{s y h}\right\} \\
& L_{1} \in\left\{L_{n e^{\prime}} L_{p^{\prime}}, L_{s y}, L_{a n}, L_{s c^{\prime}} L_{r p}\right\} \\
& W_{1} \in\left\{W_{n e^{\prime}}, W_{p^{\prime}}, W_{s y} W_{a n^{\prime}} W_{s c^{\prime}} W_{r p}\right\} \\
& W_{s 2}>W_{s 1}>W_{s 2} \\
& \text { if } f_{2}=N E \Rightarrow L_{2}=W_{2}
\end{aligned}
$$

\section{Evidence:}

$e=10 / 10$

$$
\begin{aligned}
& \text { Functional condition: } \\
& \mathrm{f}_{1} \in\{C R, H, S Y H, A C\} \\
& \mathrm{f}_{2} \in\{N E, P, S Y, C O, S C, R P\} \\
& \text { if } \mathrm{f}_{1}=C R \Rightarrow \mathrm{f}_{2} \in\{N E, P, A N\} \\
& \text { if } \mathrm{f}_{1}=H \Rightarrow \mathrm{f}_{2}=S Y \\
& \text { if } \mathrm{f}_{1}=S K H \Rightarrow f_{2}=S Y \\
& \text { if } \mathrm{f}_{1}=A C \Rightarrow \mathrm{f}_{2}=S C
\end{aligned}
$$

4 Adding a small and a large space

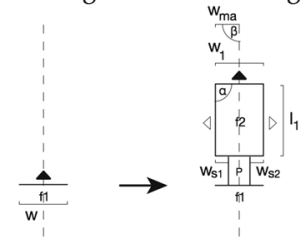

$$
\begin{aligned}
& \text { Condition: } \\
& W \in\left\{W_{c^{\prime}} W_{c c r^{\prime}} W_{n e^{\prime}} W_{p h^{\prime}}, W_{h^{\prime}}\right. \\
& \left.W_{v b^{\prime}} W_{s c^{\prime}} W_{c o}\right\} \\
& L_{1} \in\left\{L_{p h^{\prime}} L_{h^{\prime}} L_{s y h^{\prime}} L_{v b^{\prime}} L_{s c^{\prime}} L_{r p^{\prime}} L_{c 0^{\prime}}\right. \\
& L_{s y^{\prime}} \\
& \left.\quad L_{a c}\right\} \\
& W_{1} \in\left\{W_{p h^{\prime}} W_{h^{\prime}} W_{s y h^{\prime}} W_{v b^{\prime}} W_{s c^{\prime}}\right. \\
& \left.W_{r p^{\prime}} W_{c 0^{\prime}} W_{s y^{\prime}} W_{a c}\right\} \\
& w_{s 2}>W_{s 1}>W_{s 2}
\end{aligned}
$$

Evidence:

$e=10 / 10$

$$
\begin{aligned}
& \text { Functional condition: } \\
& \mathrm{f}_{1} \in\{C R, C C R, N E, P H, H, V B, S C, C O\} \\
& f_{2} \in\{P H, H, S Y H, V B, S C, R P, C O, S Y, A C\} \\
& \text { if } f_{1}=C R \Rightarrow f_{2}=\{P H, V B, S C\} \\
& \text { if } f_{1}=C C R \Rightarrow f_{2}=\{C R, A C\} \\
& \text { if } f_{1}=N E \Rightarrow f_{2}=P H \\
& \text { if } f_{1}=P H \Rightarrow f_{2}=H, S Y \\
& \text { if } f_{1}=H \Rightarrow f_{2}=S Y H \\
& \text { if } f_{1}=V B \Rightarrow f_{2}=\{S C, R P, A C\} \\
& \text { if } f_{1}=S C \Rightarrow f_{2}=R P \\
& \text { if } f_{1}=C O \Rightarrow f_{2}=C O \\
& \text { if } f_{1}=A C \Rightarrow f_{2}=V B
\end{aligned}
$$

Fig. 6 Stage I: rules to generate the basic shape of tombs. Conditions, functional conditions, and evidences are shown together with the shape and label parts of the rules

reverse a MA black label in the generation also corresponds a work step in the construction of a tomb as workman built the sanctuary before they started to build the main entrance area to the tomb. The main entrance area leads into the courtyard and is represented by a ramp and/or staircase and can include an 
5

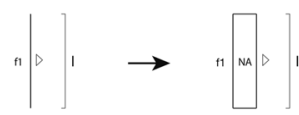

6

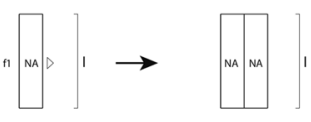

7

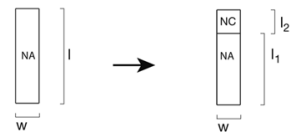

8

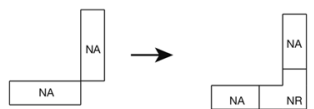

9

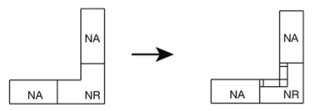

10

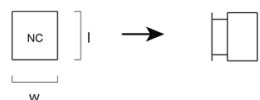

12

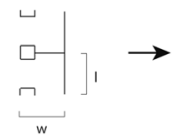

$\sqcup$
$\square$
$\square$

13

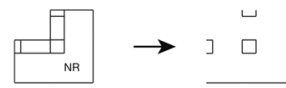

15

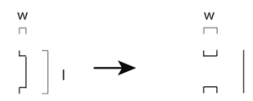

16

14

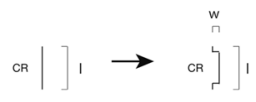

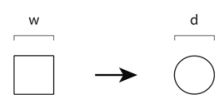

17

Fig. 7 Stage II: rules to add lateral naves and pillars along transversal side axes

18

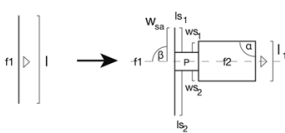

21

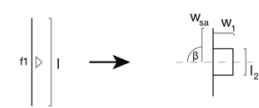

19

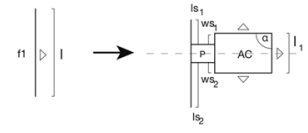

22

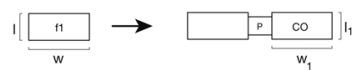

$\underset{\mathrm{w}}{[\mathrm{H}]} \mid \rightarrow$
20

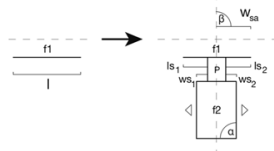

23

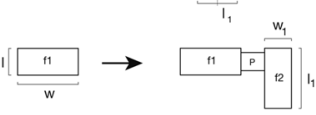

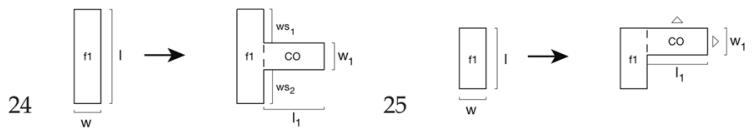

Fig. 8 Stage III: rules to add lateral annexes

additional vestibule or antechamber (Fig. 5). Archaeological evidence indicates that the construction process of the substructure of a tomb is as follows: courtyard-chiseling work for the substructure, including the sanctuaryentrance area (Eigner 1984: 69-70).

Stage $\mathrm{V}$ includes two rules, rules 32 and 33 (Fig. 10), to continue carving a passageway by detailing it with the carving of doorframes. 


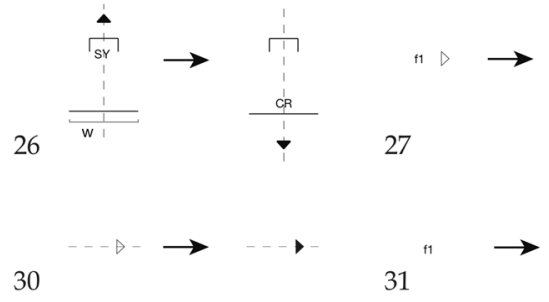

Fig. 9 Stage IV rules to change or delete labels and axes

\section{Derivation}

The described rules generate the ten substructures of the corpus but also permit the generation of new monuments. As a way of illustrating the generative capabilities of the grammar, the example of Karakhamun will be discussed here. The excavation and archaeological documentation of the courtyard of Karakhamun revealed niche-shaped spaces with pilasters (Fig. 11) on the sides of the courtyard (Pischikova 2017). The shape grammar offers the possibility of extending the courtyard, with the carving of niches corresponding to the first step in the creation of side naves and pillars. The existing situation suggests that courtyard work may not have been finished, which is also supported by the fact that decoration was unfinished as well. Rule 15 can be applied to turn a pilaster into a pillar corresponding to the construction step of carving pillars to make a side nave (Fig. 12). The analyzed corpus of monuments does not include direct evidence of the use of rule 15, but its use may be foreseen as an intermediate step in the creating of side naves. In this sense, this rule offers the possibility of completing or extending the courtyard of Karakhamun first by continuing to carve the pilasters, turning them into pillars and creating naves. This phased carving was useful in several ways: it helped organize construction and ensured that the tomb maintained a symmetrical design at each step, and could be considered completed if construction had to stop because the owner had died.

\section{Discussion and Conclusion}

The grammar for Late Period funerary monuments at Thebes is characterized by five characteristics:

Fig. 10 Stage V: rules to detail passageways

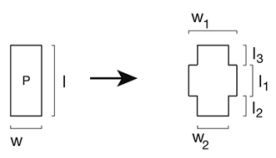

32

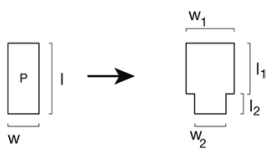




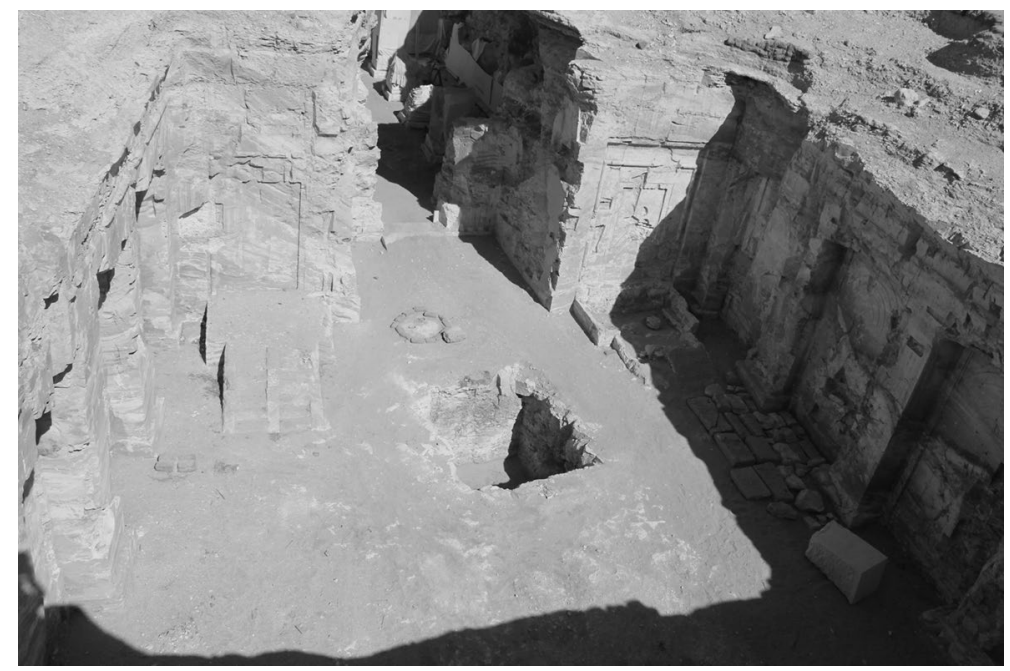

Fig. 11 Open court of the tomb of Karakhamun. In the right side of the image it is possible to see the half-carved pillars (pilasters) including base and shaft. Photograph by Katherine Blakeney. Reproduced from: (Pischikova 2017: 28). Courtesy of the South Asasif Conservation Project

- linearity — sequential development of the substructure by adding spaces along a main axis;

- symmetry-addition of spaces to both sides of the main axis along side axes;

- fractal hierarchy-repeated addition of spaces of decreasing size in depth and to the sides;

- trilogy —addition or creation of three related spaces or structures (three archways in the superstructure, three spaces added in depth and to the sides in the substructure);

- constructability - the grammar reflects the sequential carving process, that is, the chronological sequence of construction.

These characteristics of the grammar reflect features of the architecture, which was very flexible to adjust to the variety of owner status, construction time and location, and yet stylistically very coherent.

The developed grammar can generate existing tombs, reconstruct unfinished tombs, extend tombs according to the rules and probability, as the example of Karakhamun shows, or generate unknown tombs. More importantly, the rules provide a systematic, rigorous framework to describe the typology of Late Period rock-cut funerary monuments at Thebes. They also define the design language implicitly encoded in the studied monuments.

This study supports the idea that Egyptian architecture lends itself to analysis through shape grammars and opens the possibility of developing grammars to describe the architectural style of tombs from other periods and the evolution from one tomb style to another. It also suggests the possibility of developing grammars for other building types found in ancient Egyptian architecture. Unlike 


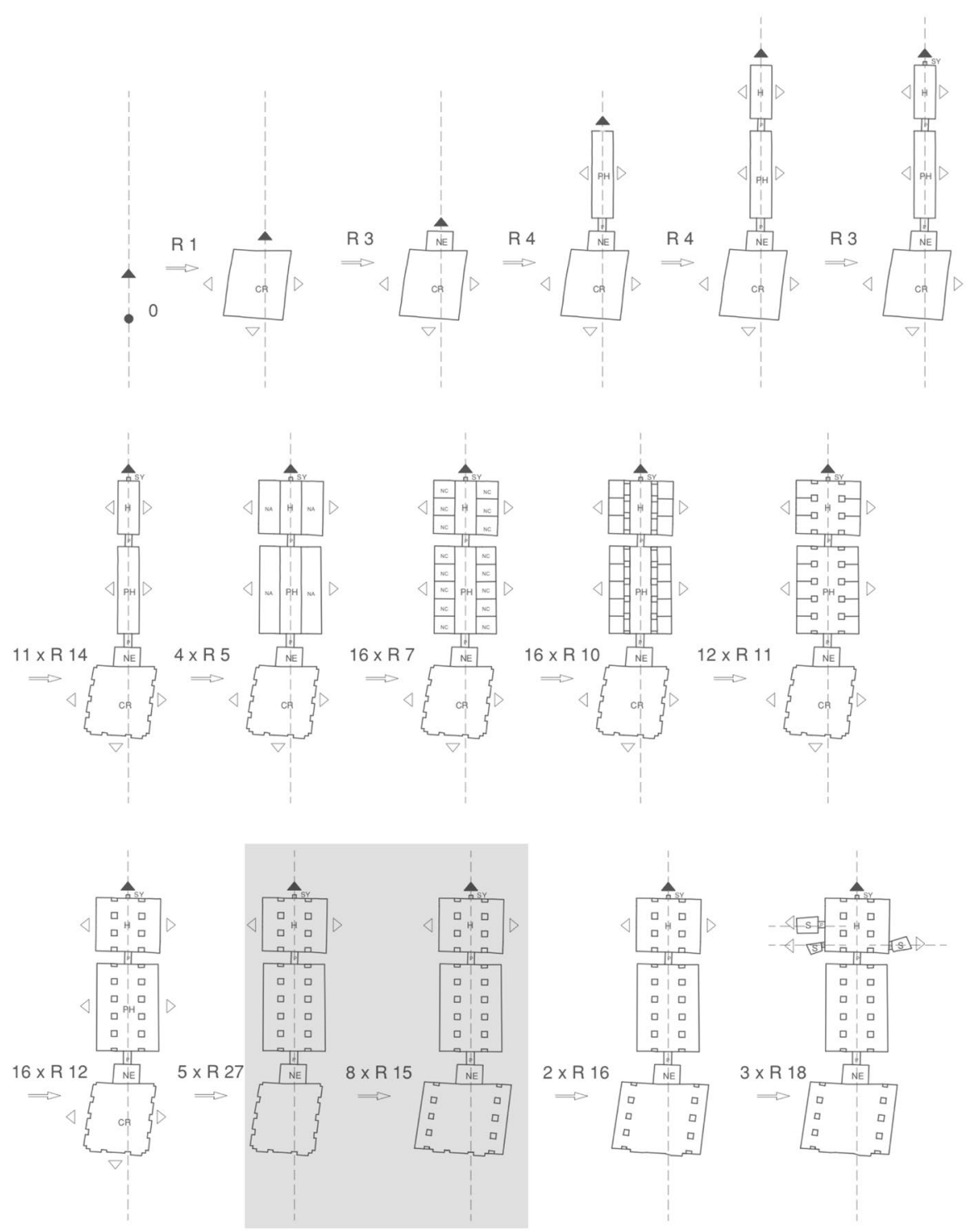

Fig. 12 Derivation of Karakhamun. The shaded area highlights the use of Rule 15 to describe the extension of the courtyard by turning pilasters into pillars and carving lateral naves

for Roman classical architecture whose rules were codified by Vitruvius and then extensively detailed and re-written in the Renaissance, no similar treatise has been found for Egyptian ancient architecture so far. However, this does not mean that such a codification did not exist or that ancient Egyptian architecture did not have a clear set of implicit canons across different building types. On the contrary, shapes and building components were reused from earlier eras 


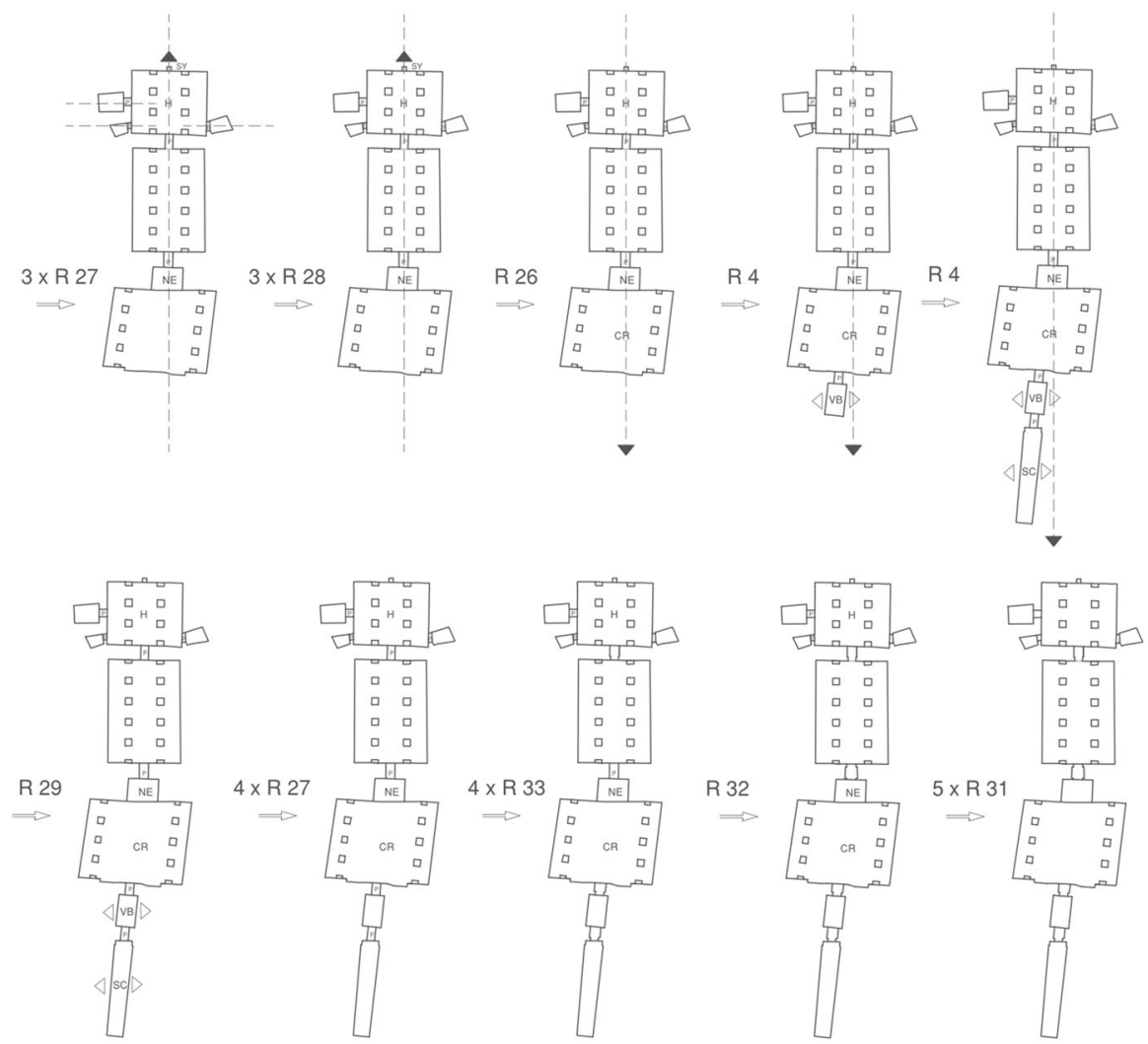

Fig. 12 (continued)

(archaisms) and new styles emerged based on given ones. Shape grammars may help in externalizing such canons and writing a treatise for ancient Egyptian architecture. Shape grammars may also help to verify hypotheses regarding the evolution of the studied tombs from older Egyptian structures, such as: the open courtyard with pillars could go back to New Kingdom private tombs at Thebes and Saqqara (Eigner 1984: 116-117); linearity and increasing sacral intensity could relate to New Kingdom tombs, both pharaonic and private (Schenkel 1995); and the predominant trilogy found in both the superstructure and the substructure may be related to Egyptian temples or even to domestic houses, as Eigner suggested. The future aim, therefore, is to develop several shape grammars encoding other design languages for reference and comparison and so be able to better identify and understand the use of shapes and spatial relations along the history of ancient Egyptian architecture. An immediate next research step could be to extend the proposed grammar to include and articulate the layouts of the different levels and their sections to gain a better understanding of the underlying rules and the associated architectural canons. The following steps would be to study tombs of other periods and locations, and then address other building types. 
Acknowledgements This research was carried out during a research visit of the first author to the Stuckeman Center for Design Computing at The Pennsylvania State University with the financial support of the Austrian Marshall Plan Foundation, TU Wien and Center for Geometry and Computational Design.

Funding Open access funding provided by TU Wien (TUW).

Open Access This article is licensed under a Creative Commons Attribution 4.0 International License, which permits use, sharing, adaptation, distribution and reproduction in any medium or format, as long as you give appropriate credit to the original author(s) and the source, provide a link to the Creative Commons licence, and indicate if changes were made. The images or other third party material in this article are included in the article's Creative Commons licence, unless indicated otherwise in a credit line to the material. If material is not included in the article's Creative Commons licence and your intended use is not permitted by statutory regulation or exceeds the permitted use, you will need to obtain permission directly from the copyright holder. To view a copy of this licence, visit http://creativeco mmons.org/licenses/by/4.0/.

\section{References}

Bagnall, Roger S. 2009. Practical Help: Chronology, Geography, Measures, Currency, Names, Prosopography, and Technical Vocabulary. The Oxford Handbook of Papyrology. https://doi. org/https://doi.org/10.1093/oxfordhb/9780199843695.013.0008

Belzoni, Giovanni B. 1821. Voyages En Égypte Et En Nubie, Contenant Le Récit Des Recherches Et Découvertes Archéologiques Faites Dans Les Pyramides, Temples, Ruines Et Tombes De Ces Pays. Suivis D'Un Voyage Sur La Côte De La Mer Rouge Et A L'Oasis De Jupiter Ammon I-III. Paris.

Bietak, Manfred and Elfriede Reiser-Haslauer. 1978. Das Grab des Anch-Hor, Obersthofmeister der Gottesgemahlin Nitokris, Teil I. Mit einem Beitrag von E. Graefe und Relief- und Fundzeichnungen von H. Satzinger. Untersuchungen der Zweigstelle Kairo des Österreichischen Archäologischen Instituts 4. Wien: Verlag der Österreichischen Akademie der Wissenschaften.

Bietak, Manfred and Elfriede Reiser-Haslauer. 1982. Das Grab des Anch-Hor, Obersthofmeister der Gottesgemahlin Nitokris, Teil II. Mit einem Beitrag von J. Boessneck, A. von den Driesch, Jan Quaege-beur, H. Liese-Kleiber und H. Schlichtherle und Relief- und Fundzeichnungen von H. Satzinger. Untersuchungen der Zweigstelle Kairo des Österreichischen Archäologischen Instituts 5. Wien: Verlag der Österreichischen Akademie der Wissenschaften.

Corsi, Alessio. 2017. A preliminary report on the identification of the texts in the pillared hall of the Tomb of Pabasa (TT 279). Göttinger Miszellen: Beiträge zur ägyptologischen Diskussion 252: 29-40.

Downing, Frances and Ulrich Flemming. 1981. The Bungalows of Buffalo. Environment and Planning B: Planning and Design 8: 269-293.

Eigner, Diethelm. 1984. Die monumentalen Grabbauten der Spätzeit in der thebanischen Nekropole I. Wien: Verlag der Österreichischen Akademie der Wissenschaften.

Eigner, Diethelm and Josef Dorner. 1984. Die monumentalen Grabbauten der Spätzeit in der thebanischen Nekropole II. Wien: Verlag der Österreichischen Akademie der Wissenschaften.

Gestermann, Louise and Farouk Gomaà. 2018. Remarks on the Decoration and Conception of the Theban Tomb of Montuemhat (TT 34). Thebes in the First Millenium BC. Art and Archaeology of the Kushite Period and Beyond: 152-161.

Gomaà, Farouk. 2004. Bericht über die Freilegung des Grabes TT 197 des Padineith. Memnonia 15: 183-196.

Gomaà, Farouk. 2006. Die Arbeiten am Grab des Monthemhet. Sokar 12: 62-64.

Graefe, Erhart. 2003. Das Grab des Padihorresnet: Obervermögensverwalter der Gottesgemahlin des Amun (Thebanisches Grab Nr. 196). Brüssel: Brepols.

Hay, Robert. 1824. Diary. British Library, Manuscript collections, Add MSS 29812-60, 31054

Koning, Hank and Julie Eizenberg. 1981. The language of the prairie: Frank Lloyd Wright's prairie houses. Environment and Planning B: Planning and Design 8: 295-323. 
Lansing, Ambrose. 1920. The Egyptian Expedition 1916-1919. II: Excavations in the Asasif at Thebes. Season of 1918-1919. The Metropolitan Museum of Art Bulletin 15: 11-24.

Lepsius, Karl R. 1849. Denkmäler aus Ägypten und Äthiopien. Berlin.

$\mathrm{Li}$, Andrew I-kang. 2001. Teaching style grammatically, with an example from traditional Chinese architecture. The proceedings of Mathematics \& design 2001: 270-277

Mackay, William I. and Neander Silva. 2012. Archaeology, Incas, Shape Grammars and Virtual Reconstruction. Emerging Trends in Computing, Informatics, Systems Sciences, and Engineering: $1121-1131$.

Mamoli, Myrsini. 2019. Shape Grammars as a Probabilistic Model for Building Type Definition and Computation of Possible Instances: The Case Study of Ancient Greek and Roman Libraries. Design Computing and Cognition '18: 459-477.

Nasr, Mohammed A. 1985. Report on the Restoration of the Tomb of Pabasa (TT 279). Mitteilungen des Deutschen Archäologischen Instituts, Abteilung Kairo 41: 189-196.

Pischikova, Elena (ed.). 2014. Tombs of the South Asasif Necropolis. Cairo: The American University in Cairo Press.

Pischikova, Elena. 2017. Tombs of the South Asasif Necropolis: New Discoveries and Research 20122014. Cairo: The American University in Cairo Press.

Pischikova, Elena, Julia Budka and Kenneth Griffin (eds.). 2014. Thebes in the First Millenium BC. Cambridge: Cambridge Scholars Publishing.

Pischikova, Elena, Julia Budka and Kenneth Griffin (eds.). 2018. Thebes in the First Millenium BC. Art and Archaeology of the Kushite Period and Beyond. London: Golden House Publications.

Pococke, Richard. 1743. A description of the East and some other countries. I. London.

Schenkel, Wolfgang. 1995. Zur Typologie des Felsfassadengrabes. Thebanische Beamtennekropolen. Studien zur Archäologie und Geschichte Altägyptens: 12. Neue Perspektiven archäologischer Forschung. Internationales Symposion Heidelberg 9-13.6.1993: 169-184.

Stiny, George and James Gips. 1972. Shape grammars and the generative specification of painting and sculpture. Information Processing 71, Proceedings of the IFIP Congress 1971, 2: 125-135.

Stiny, George and William J. Mitchell. 1978. The Palladian Grammar. Environment and Planning B 5: $5-18$.

Tiradritti, Francesco. 2004. La tomba di Harwa. L'enigma di Harwa: alla scoperta di un capolavoro del rinascimento egizio: $167-207$.

Tiradritti, Francesco. 2015. Il cammino di Harwa. Un percorso iniziatico in un monumento tebano del VII Sec. A.C. Egitto in Italia, Italia in Egitto. Suggestioni, successi e influenze recipro- che nella storia: $102-132$.

Traunecker, Claude. 2014. The "Funeral Palace" of Padiamenope: Tomb, Place of Pilgrimage, and Library. Current Research. In: Thebes in the First Millenium BC, Elena Pischikova, Julia Budka and Kenneth Griffin, eds, 205-234 (Newcastle upon Tyne: Cambridge Scholars Publishing).

Traunecker, Claude. 2018. Abydenian Pilgrimage, Immortal stars and Theban Liturgies in the Tomb of Padiamenope. Thebes in the First Millenium BC. Art and Archaeology of the Kushite Period and Beyond, Elena Pischikova, Julia Budka and Kenneth Griffin, eds., 126-151. London: Golden House Publications.

Wutte, Anja, Peter Ferschin and Georg Suter. 2015. Excavation goes BIM. Building Analysis of an Egyptian Funerary Monument with Building Information Modeling Methods. Proceedings of the 20th International Conference on Cultural Heritage and New Technologies.

Wutte, Anja. 2018. Data visualization of decoration occurrence and distribution . A comparative study of Late Egyptian funerary decoration in Thebes. Proceedings of the Eurographics Workshop on Graphics and Cultural Heritage: 113-117.

Publisher's Note Springer Nature remains neutral with regard to jurisdictional claims in published maps and institutional affiliations.

Anja Wutte holds Master degrees in Egyptology and Classical Archaeology from University of Vienna. Currently she is a PhD candidate at TU Wien (Vienna University of Technology) at the interdisciplinary Center for Geometry and Computational Design. Her dissertation topic is "The Grammar of Late Period funerary monuments of Thebes". Architectural analysis of spaces and their architectural properties (e.g. 
natural lighting, accessibility of spaces) as well as procedural modeling to form a parametric corpus of design and construction principles of Late Egyptian funerary monuments are essential parts of her research.

Jose Pinto Duarte (Lic Arch UT Lisbon 1987, SMArchS 1993 and PhD MIT 2001) is the Stuckeman Chair in Design Innovation and director of the Stuckeman Center for Design Computing at Penn State, where he is Professor of Architecture and Landscape Architecture, and Affiliate Professor of Architectural Engineering and Engineering Design. Dr. Duarte was dean of the Lisbon School of Architecture and president of eCAADe. He was co-founder of the Penn State Additive Construction Laboratory (AddCon Lab) and his research interests are in the use of computation to support context-sensitive design at different scales. Recently, he co-edited (with Branko Kolarevic) the book "Mass Customization and Design Democracy" (Routledge, NY, 2019) and his team was awarded 2nd place in the finals of the "NASA 3D Printed Mars Habitat Challenge." 